\title{
PENGARUH LILIN AROMATERAPI MINYAK LAVENDER (LAVANDULA ANGUSTIFOLIA) TERHADAP KONSENTRASI BELAJAR PADA SISWA MADRASAH TSANAWIYAH AL-WASHLIYAH PASAR MIRING DI DESA PASAR MIRING
}

\author{
RATIH ANGGRAENI ${ }^{1}$, MURIATI ${ }^{2}$, CHANDRA PRANATA ${ }^{3}$ \\ Institut Kesehatan Medistra Lubuk Pakam, Jl. Sudirman No.38 Lubuk Pakam \\ Kabupaten Deli Serdang, Provinsi Sumatera Utara \\ e-mail:ratihanggraeni1312@gmail.com \\ DOI $10.35451 / \mathrm{jfm} . v 3 i 2.678$
}

\begin{abstract}
Aromatherapy is an ancient healing process that uses pure aromatherapy plant extracts aimed at improving the health and well-being of the body, mind and spirit. Lavender contains linalil acetate and linalool. Linalil acetate and linalool have no harmful side effects on health. This substance is antibacterial, fungicidal, viriside, parasiticidal and vermifugal and has neurotonic and uterotonic action. This study aims to determine the effect of lavender oil (Lavandula angustifolia) aromatherapy candles on increasing the concentration of student learning at the Madrasah Tsanawiyah Al-Wasliyah Pasar Miring in Desa Pasar Miring. The study used a quasi-pretest-posttest experimental method for 30 randomly selected students. The instrument in this study used the Army Alpha Test with data analysis using Paired T-Test. Hypothesis testing using Paired T-Test showed $p$ value $=0.026<0.05(p<0.05)$. It can be concluded that there is an influence of lavender oil aromatherapy candles on increasing the concentration of student learning in Madrasah Tsanawiyah AlWasliyah Pasar Miring in Desa Pasar Miring
\end{abstract}

Keywords: aromaterapy, candle, oil atsiri, lavender.

\section{PENDAHULUAN}

Indonesia termasuk salah satu negara yang dikenal dapat menghasilkan minyak atsiri dalam jumlah besar. Indonesia banyak mengekspor minyak atsiri hingga mencapai $90 \%$ dari total produksi setiap tahunnya. Indonesia memiliki banyak tanaman penghasil minyak atsiri yang masih belum dikembangkan dengan optimal. Indonesia menghasilkan 40 jenis dari 80 jenis minyak atsiri yang diperdagangkan pasar dunia. Aromaterapi memiliki beberapa fungsi diantaranya menjadikan udara dalam ruangan segar, menciptakan suasana tenang, dapat digunakan sebagai antibiotik, dapat digunakan sebagai antiseptik untuk melawan virus, merendam emosi, dapat menjadi alat relaksasi, dan dapat meningkatkan konsentrasi belajar.

Belajar merupakan perubahan persepsi dan pemahaman. Perubahan persepsi dan pemahaman tidak selalu berupa perubahan perilaku yang dapat 
diamati. Perkembangan kognitif, perkembangan berpikir dan cara kerja aktivitas berpikir (Syaodih, 2011).

Kurangnya konsentrasi dan minat belajar antara lain disebabkan oleh lingkungan yang kurang berminat memperhatikan mata, kondisi lingkungan, pikiran kacau atau gangguan kesehatan yang tidak terganggu, kejenuhan sekolah dan lainlain. (Slameto, 2010).

Selain itu beberapa faktor yang menyebabkan gangguan konsentrasi belajar yaitu, tidak adanya motivasi diri, suasana lingkungan belajar yang tidak kondusif, kondisi kesehatan siswa, serta tingkat kejenuhan menjadi penyebab gangguan konsentrasi belajar (Nugroho, 2007). Aromaterapi yang digunakan melalui cara inhalasi atau dihirup akan masuk ke sistem limbic dimana nantinya aromaterapi ini akan di proses sehingga dapat mencium baunya. Saat Anda menghirup suatu aroma, komponen kimiawi akan memasuki sistem limbik di otak. Amigdala sebagian berada dalam sistem limbik yang bertanggung jawab atas respons emosional kita terhadap bau. Hipokampus bertanggung jawab untuk mengenali ingatan dan bau serta tempat di mana bahan kimia dalam aromaterapi merangsang penyimpanan memori di otak kita untuk mengenali bau. Ini akan merangsang memori dan respons emosional (Dewi, 2011).

Lavender diketahui dapat meningkatkan gelombang alfa di dalam otak dan membuat seseorang merasa rileks. Lavender mengandung linalil asetat dan linalool yang diketahui tidak memiliki efek samping berbahaya bagi kesehatan. Linalil asetat dan linalool dapat membunuh bakteri, jamur virus, parasit, serta vermifugal. Linalil asetat dan linalool bekerja secara neurotonik dan uterotonik (Sharma, 2009). Aromaterapi merupakan proses penyembuhan kuno yang menggunakan sari tumbuhan aromaterapi murni yang bertujuan untuk meningkatkan kesehatan dan kesejahteraan tubuh, pikiran dan jiwa (Goel, 2005).

Lilin aromaterapi dalam pembuatannya menggunakan beberapa bahan dan salah satunya menggunakan minyak atsiri yang memiliki wangi aromaterapi. Aromaterapi sendiri memiliki khasiat yang menenangkan dan juga memiliki aroma yang menyegarkan (Jaelani, 2009).

Lavender mengandung linalil asetat dan linalool. Linalil asetat dan linalool tidak mempunyai efek samping yang berbahaya terhadap kesehatan. Zat inibersifat antibakteri, fungisida, viricidal, parasitic, dan vermifugal serta memiliki kerja neurotonik dan uterotonik. Aromaterapi lavender bekerja dengan mempengaruhi kerja otak. Aromaterapi lavender yang harum dan segar memberikan banyak manfaat bagi kesehatan psikologis seseorang. (Nurkhasanah, 2005).

Berdasarkan hasil survey awal di Madrasah Tsanawiyah Swasta AlWashliyah Pasar Miring di Desa Pasar Miring dengan populasi 198 siswa. Dengan populasi sampel 33 orang siswa kelas VII, dengan jumlah siswa laki-laki berjumlah 15 orang dan perempuan berjumlah 18 orang. Berdasarkan latar belakang diatas maka penulis tertarik untuk melakukan penelitian tentang PengaruhLilin Aromaterapi Minyak Lavender (Lavandul Angustifolia) Terhadap Konsentrasi Belajar Pada Siswa Madrasah Tsanawiyah Swasta AlWashliyah Pasar Miring Di Desa Pasar Miring.

\section{METODE PENELITIAN}

Jenis penelitian ini menggunakan metode Quasi Eksperiment dengan pre eksperimen desain dan post eksperimen desain dimana dilakukan sebelum diberi lilin aromaterapi dan sesudah diberikan lilin aromaterapi.yang dimaksudkan untuk melihat konsentrasi belajar pada siswa Madrasah Tsanawiyah Al- 
Washliyah Pasar Miring di Desa Pasar Miring.

\section{Lokasi dan Waktu Penelitian}

Penelitian ini dilaksanakan di Madrasah Tsanawiyah Al Washliyah Pasar Miring di Desa Pasar Miring. Waktu penelitian dilakukan pada bulan juni yaitu pengujian pengaruh digunakan sebagai populasi dalam penelitian ini karena populasi diketahui jumlahnya (populasi terhingga) maka dapat digunakan rumus Slovin.

$\mathrm{n}=\frac{N}{1+N(e 2)}$

Dimana :

$\mathrm{n}=$ Jumlah sample

$\mathrm{N}=$ Jumlah populasi

e $=$ Toleransi error yang di pilih (5\%)

Sehingga berdasarkan rumus Solvin tersebut di dapat:

$$
\begin{gathered}
\mathrm{n}=\frac{N}{1+N(e 2)} \\
\mathrm{n}=\frac{33}{1+33(0,0025)} \\
\mathrm{n}=\frac{33}{1+0,0825} \\
\mathrm{n}=\frac{33}{1,0825}=30
\end{gathered}
$$

Jumlah sampel yang harus diteliti sebanyak 30 orang

\section{Sampel}

Sampel adalah sebagian dari populasi. Subyek penelitian lilin aroma terapi minyak lavender terhadap Siswa Madrasah Tsanawiyah Al Wasliyah Pasar Miring di Desa Pasar Miring.

\section{Populasi dan Sampel}

Populasi merupakan wilayah yang terdiri atas obyek/subyek berkarakteristik tertentu yang ditetapkan untuk diteliti (Sugiyono, 2011).

Dalam penelitian ini, peneliti mengambil populasi yaitu siswa-siswi kelas VII Madrasah Tsanawiyah Swasta Al-Wasliyah Pasar Miring sebanyak 33 orang. Diperoleh responden sebanyak 30 siswa-siswi yang selanjutnya menjadi sampel penelitian ini adalah representative dari popuilasi jadi tidak seluruhnya subjek dari populasi diteliti.

\section{Teknik pengumpulan data}

Penelitian ini mengumpulkan data dengan melakukan pengukuran yang di ambil dari hasil soal Army Alpha Tens yang berbentuk soal psikotes

\section{Prosedur Pelaksanaan Penelitian}

Penelitian ini dilakukan melalui tiga tahap, yaitu tahap persiapan, pelaksanaan dan tahap akhir (pengolahan data)

\section{ANALISIS DATA}

Teknik yang digunakan yaitu uji Paired T-Test atau uji beda. yang akan dibedakan skor subjek pretest dengan skor subjek posttest. Hasil yang diperoleh berupa score, yaitu selisih skor pretest dan posttest. Perbedaannya diberikan perlakuan dengan skor subjek pada posttest atau pengukuran setelah diberikan perlakukan, diberikan perlakuan skor subjek pada posttest (Seniati, 2008).

\section{Analisis Univariat}

Analisis univariat ini dilakukan untuk memperoleh gambaran/deskripsi pada masing-masing variabel bebas maupun variabel terikat. Adapun variabel bebas pada penelitian ini yaitu pengaruh lilin aromaterapi minyak lavender dan variabel terikat berupa konsentrasi belajar siswa.

\section{Analisis Bivariat}

Teknik analisis data yang digunakan pada penelitian ini adalah teknik analisis statistik dengan uji Paired T-Test. Dimana pada uji ini dilakukan 2 buah perlakuan yang berbeda yaitu perlakuan pertama saat dilakukan tes potensi pertama, reponden tidak diberi lilin aromaterapi minyak lavender dan 
pada saat dilakukan tes potensi yang kedua, responden diberikan lilin aromaterapi minyak lavender di sudutsudut ruangan.

\section{HASIL DAN PEMBAHASAN}

penelitian ini tentang lilin aromaterapi minyak lavender terhadap konsentrasi belajar siswa di Madrasah Tsanawiyah Al-Washliyah Pasar Miring, sekolah ini terletak di Desa Pasar Miring Kecamatan Pagar Merbau. Memiliki jumlah siswa keseluruhan sebanyak 190 siswa yang belajar di Madrasah Tsanawiyah AlWasliyah Pasar Miring.

\section{Data Univariat}

\section{a. Karakteristi}

\section{Berdasarkan Jenis Kelamin}

Sumber : Olahan Data SPSS

Berdasarkan tabel 4.1 dapat diketahui sebagian kecil responden yang berjenis kelamin laki-lak i sebanyak 12 responden $(40 \%)$ dan sebagian besar responden berjenis kelamin perempuan sebanyak 18 responden (60\%).

b. Karakteristik

Responden Berdasarkan Usia

\begin{tabular}{|c|c|c|}
\hline Usia & Frequency & Percent \\
\hline 13 & 27 & 90.0 \\
\hline 14 & 3 & 10.0 \\
\hline Total & 30 & 100.0 \\
\hline
\end{tabular}

Sumber : Olahan Data Statistik

Berdasarkan hasil analisis tabel table. 1 didapatkan bahwa pada kelompok dengan usia minimal 13 tahun dan maksimal 14 tahun. Responden dengan karakteristik usia responden dengan usia 13 tahun sebanyak 27 orang $(90 \%)$ dan usia 14 tahun sebanyak 3 orang (10\%).

\section{c. Mengidentifikasi Tingkat} Konsentrasi Belajar Siswa Sebelum Diberikan Lilin Aromaterapi Minyak Lavender.
Berikut adalah hasil dari uji paired t-test sebelum diberikan lilin aromaterapi minyak lavender. Miring

Tsanawiyah Al- Washliyah Pasar

Berdasarkan tabel 2 dapat diketahui

\begin{tabular}{|c|c|c|}
\hline $\begin{array}{l}\text { Tabel } 2 . \\
\text { Responden } \\
\text { Kelamin. }\end{array}$ & $\begin{array}{l}\text { Dist } \\
\text { Berc }\end{array}$ & $\begin{array}{l}\text { Frekuensi } \\
\text { n Jenis }\end{array}$ \\
\hline $\begin{array}{l}\text { Jenis } \\
\text { Kelamin }\end{array}$ & $\mathbf{F}$ & Percent \\
\hline Lk & 12 & 40.0 \\
\hline $\mathrm{Pr}$ & 18 & 60.0 \\
\hline Total & 30 & 100.0 \\
\hline
\end{tabular}
didapatkan rata-rata 26 yang artinya responden memiliki perilaku terhadap konsenstrasi belajar, 20 yang artinya nilai tengah, nilai yang sering muncul yaitu 40 , nilai minimum adalah 0 dan nilai maksimum adalah 60 .

d. Mengidentifikasi Tingkat Konsentrasi Belajar Siswa Sesudah Diberikan Lilin Aromaterapi Minyak Lavender.

Berikut adalah hasil dari uji paired t-test sesudah diberikan lilin aromaterapi lavender.

\begin{tabular}{|c|c|c|}
\hline \multicolumn{3}{|c|}{ POST TEST } \\
\hline \multirow[t]{2}{*}{$\mathbf{N}$} & Valid & 30 \\
\hline & Missing & 0 \\
\hline \multicolumn{2}{|c|}{ Mean } & 84.00 \\
\hline \multicolumn{2}{|c|}{ Median } & 80.00 \\
\hline \multicolumn{2}{|c|}{ Mode } & 80 \\
\hline \multicolumn{2}{|c|}{ Minimum } & 40 \\
\hline \multicolumn{2}{|c|}{ Maximum } & 100 \\
\hline
\end{tabular}

Tabel 3. Sumber: Olahan Data SPSS

dapat diketahui bahwa pada kelompok post test di dapatkan rata-rata 84 yang artinya responden mengalami peningkatan konsentrasi belajar, 80 yang artinya nilai tengah, nilai yang sering muncul yaitu 80 , nilai minimum adalah 40 dan maksimum adalah 100 


\section{DATA BIVARIAT}

\section{a. Menganalisis pngaruh Pemberian Lilin Aroma Terapi Minyak Lavender Terhadap Konsentrasi Belajar Siswa.}

Menganalisis Pengaruh Pemberian Lilin Aroma Terapi Minyak Lavender Terhadap Konsentrasi Belajar Siswa Tabel 4.5 Hasil Analisis Pengaruh Pemberian Lilin Aromaterapi Minyak Lavender Terhadap Peningkatan Konsentrasi Belajar Siswa Di Madrasah Tsanawiyah Al-Wasliyah Pasar Miring di Desa Pasar Miring.

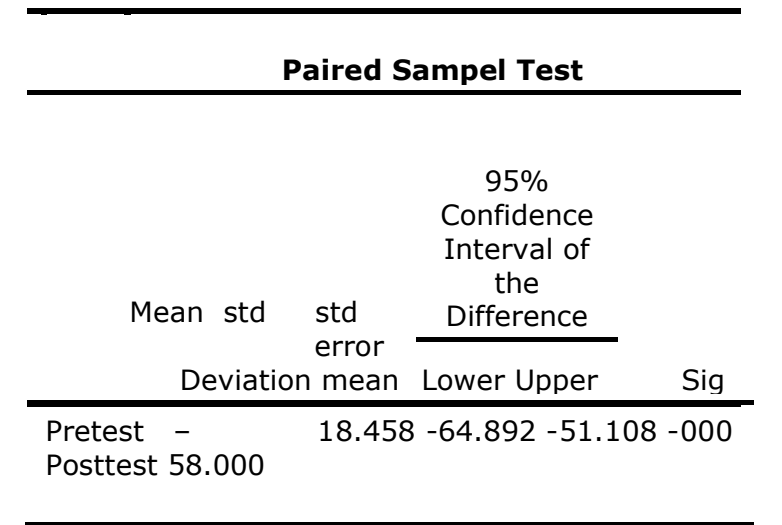

\section{Sumber: Olahan Data SPSS}

Berdasarkan tabel 4.5 di atas menunjukkan bahwa pemberian lilin aromaterapi minyak lavender memiliki pengaruh terhadap peningkatan konsentrasi belajar siswa.

Berdasarkan hasil analisa dengan menggunakan uji syatistic paired $t$-test sample ber pasangan dengan program aplikasi dari SPSS di dapatkan $p$ value $=$ $0,026<\mathrm{a}=0.05$, artinya $\mathrm{H}_{0}$ ditolak dan $\mathrm{H}_{\mathrm{a}}$ diterima, berarti ada pengaruh pemberian lilin aromaterapi minyak lavender terhadap peningkatan konsentrasi belajar siswa Di Madrasah Tsanawiyah Al-Wasliyah Pasar Miring Di Desa Pasar Miring.

Hasil uji statistic paired t-test sample berpasangan bahwa $r$ hitung $=$ 0.406 yaitu positif yang berarti semakin sering diberikan lilin aromaterapi minyak lavender maka ada peningkatan pada konsentrasi belajar siswa.

\section{PEMBAHASAN}

Dari hasil penelitian yang dilakukan pada bulan juni 2020 tentang Pengaruh
Pemberian Lilin Aromaterapi Minyak Lavender (Lavandula angustivolia) Terhadap Konsentrasi Belajar Pada Siswa Madrasah Tsanawiyah AlWasliyah Pasar Miring di Desa Pasar Miring dengan jumlah responden sebanyak 30 orang siswa kelas VII menggunakan instrumen armyalpha test.Berdasarkan hasil penelitian tabel 4.3 terhadap 30 responden siswa kelas VII didapat nilai $p$ value $=0,026<a=$ 0.05 , sehingga dapat dikatakan bahwa terdapat hubungan antara pretest dan post test dalam pemberian lilin aromaterapi minyak lavender

Hasil penelitian selaras dengan penelitian yangdilakukan Evanjelis pada tahun 2015 yangmenyatakan waktu reaksi merupakan hal pentingyang dibutuhkan seseorang ketika melakukan suatuaktivitas yang memerlukan kosentrasi penuh.dengan hasil pengaruh aromaterapi lemon minyak lavender terhadap waktu reaksi diuji menggunakanuji " $t$ " berpasangan sebelum dan sesudah diperoleh nilai $p<$ 0,05 (Evanjelis,2015).

Aromaterapi digunakan dengan cara inhalasi akan masuk ke istem limbik. Amigdala dalam sistem limbik bertanggung jawab atas respon emosi kitaterhadap aroma. Hippocampus bertanggung jawabatas memori dan pengenalan terhadap bau jugatempat dimana bahan kimia pada aromaterapimerangsang gudanggudang penyimpanan memoriotak kita terhadap pengenalan bau-bauan. Hal ini bahkan merangsang memori dan respon emosional (Dewi,2011).

Minyak lavender yang mengandung linalool menjadi salah satu aromaterapi yang banyak digunakan, penggunaan paling sering dari aromaterapi ini adalah secara inhalasi atau dihirup. Aroma terapi berdampak baik pada penurunan tingkat kecemasan. Apabila diberikan langsung secara inhalasi ke hidung akan terjadi kontak langsung dengan otak. Aroma lavender bekerja mempengaruhi sistem kerja limbik. Pesan yang sampai akan berubah menjadi reaksi akibat pelepasan hormon melatonin dan serotonin yang menyebaban euporia, relaks atau sedatif (Koensoemardiyah,2009). 


\section{Berdasarkan nilai rata-rata} tingkat konsentrasiyang diperoleh dari hasil penelitian serta teori yangada maka disimpulkan bahwa lilin aromaterapi minyak lavender (Lavandula angusitifolia) berpengaruh padaperubahan tingkat konsentrasi belajar, perubahanyang terjadi berupa peningkatan konsentrasi belajar.

\section{DAFTAR PUSTAKA}

Ali B, Al-Wabel NA, Shams S,Ahamad

A, Khan SA, Anwar F. (2015).

Essential Oils Used In

Aromatherapy: A Systemic

Review. Asian Pac J Trop

Biomed Elsevier (Singapore)

Pte Ltd;5(8):601- 11.

Buchbauer, et al. Formulation and Activity Combination of Essential Oil in Aromatherapy ofWax.JournaofEssentialOilRe search.2017;6(1) :124127.

Bhanu PV and Lakshmi P K.Development And Optimization Of Novel Diclofenac Emulgel for Topical Drug Delivery.Internat JComparePharmacy.2011;9(1 $0)$ : 1-4.

Djamarah,S.,\& Bahri.(2008). Rahasia Sukses Belajar. Jakarta: Rineka Cipta.

Engkoswara \& Komariah, Aan.(2012). AdministrasiPendidikan .nadun g: Alfabeta.

Geetha, R.V., and Roy, A., 2014. Essential Oil Repellents- A short Review. Chennai: IJDDR, 6 (2): 20-27.

Homby \& Siswoyo.(1993). Kamus Inggris-Indonesia. Jakarta: Indira.

Poerwadi, R. (2006). Aromaterapi Sahabat Calon Ibu. Jakarta: Dian Rakyat.

Suryabrata,S. (2011).Metode Penelitian. Jakarta: Rajawali. 